\title{
Audiência de custódia: Crivo judicial das prisões cautelares
}

\section{Custody hearing: Judicial screening of pre-trial detention}

DOI: $10.54018 /$ sssrv2n2-004

\section{Felipe Teles Tourounoglou}

Mestre em direito - Professor Universitário

\section{RESUMO}

Este trabalho tem como escopo apresentar a Audiência de Custódia como crivo judicial das prisões cautelares no Brasil, por conseguinte, também demonstrará que tal instituto tem o condão de evitar a violação dos direitos e garantias fundamentais do homem. $O$ instituto é apresentado imbuído do contexto neoconstitucionalista em que os direitos humanos estão inseridos, bem como a existência dos tratados internacionais que versam sobre os direitos do homem. Trata-se de um estudo que busca analisar a problemática fática das prisões cautelares, abordada através do caos do sistema penitenciário brasileiro.

Palavras-chave: Direitos Humanos, Tratados Internacionais, Audiência de Custódia, Prisões Provisórias Cautelares.

\section{ABSTRACT}

The purpose of this work is to present the Hearing of Custody as a judicial review of the precautionary prisons in Brazil, therefore, it will also demonstrate that such an institution has the ability to avoid violation of the fundamental rights and guarantees of man. The institute is presented imbued with the neoconstitutionalist context in which human rights are embedded, as well as the existence of international treaties dealing with human rights. It is a study that tries to analyze the problematic problematic of the precautionary prisons, approached through the chaos of the Brazilian penitentiary system.

Keywords: Human Rights, International Treaties, Custody Hearing, Precautionary Provisional Prisons.

\section{INTRODUÇÃO}

O presente artigo verifica a Audiência de Custódia como solução possível e eficaz para filtrar o encarceramento cautelar, de modo a reduzir não somente a superlotação carcerária, mas também promover a ascensão dos direitos do homem contidos à Constituição Federal e nos tratados internacionais dos quais o 
estado brasileiro é signatário.

Para isto, utilizou-se como método de desenvolvimento deste estudo a análise doutrinária, leitura da legislação pátria em consonância com 0 posicionamento do Superior Tribunal Federal sobre o tema, bem como leitura dos tratados internacionais, análise de pesquisas oficiais nacionais e reportagens de revistas eletrônicas conceituadas.

O tema será abordado com o método dedutivo a partir do uso de concepções e teorias já existentes acerca da criação do instituto da Audiência de Custódia, bem como a legalidade de sua implementação no país e a real importância que a sua utilização efetiva trará aos direitos do homem.

Trabalha-se com a hipótese de que a Audiência de Custódia é o crivo para se evitar os encarceramentos provisórios desnecessários, ao passo que, por consequência, também se evitará que os direitos humanos e as garantias fundamentais do homem sejam violados.

Neste ínterim, impõe-se a análise de outros temas, com o objetivo de contextualizar o instituto, bem como a sua importância na realidade fática e social do país.

\section{AUDIÊNCIA DE CUSTÓDIA INSTITUIÇÃO NO BRASIL E NEOCONSTITUCIONALISMO}

\subsection{CONVENÇÃO AMERICANA DOS DIREITOS HUMANOS.}

De acordo com o artigo 1ํ do Decreto de n. 678 de setembro de 1992, o qual ratificou a Convenção Americana sobre Direitos Humanos (também conhecida como o Pacto de São José da Costa Rica), depreende-se que esta fora "celebrada em São José da Costa Rica, em 22 de novembro de 1969, apensa por cópia ao presente decreto, deverá ser cumprida tão inteiramente como nela se contém".

Ademais, acerca de sua validade dentro do pátrio ordenamento jurídico, importante destacar o disposto no artigo 5a , parágrafos $1^{\circ}$ e $2^{\circ}$ da Constituição da República Federativa do Brasil, os quais garantem ao Pacto de São José da Costa Rica a característica de norma supra legal, com o poder, portanto, de derrogar as disposições contrárias inseridas em legislações infraconstitucionais. In verbis: 
$\S 1^{\circ}$ As normas definidoras dos direitos e garantias fundamentais têm aplicação imediata.

$\S 2$ O Os direitos e garantias expressos nesta Constituição não excluem outros decorrentes do regime e dos princípios por ela adotados, ou dos tratados internacionais em que a República Federativa do Brasil seja parte.

Ademais, além do que dispõe referido texto constitucional, extrai-se que o Supremo Tribunal Federal posicionou-se no sentido de considerar inconstitucional a prisão do depositário infiel, com fulcro nas disposições da Convenção Americana dos Direitos Humanos. Logo, ao entender o Pretório Excelso deste modo, isto é, posicionando-se no sentido de desconsiderar o disposto em lei infraconstitucional, para então aplicar o que traz o Pacto de São José da Costa Rica, imperioso é que se mantenha a mesma interpretação para as demais disposições que também estão abaixo da Constituição Federal, como é o caso da aplicação da Audiência de Custódia.

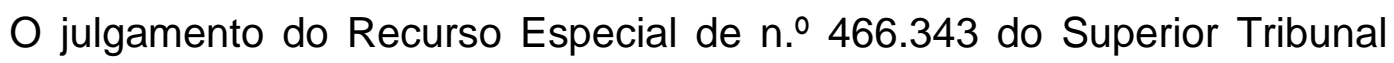
Federal pacificou seu entendimento pela supralegalidade dos tratados internacionais que tratam dos direitos humanos e a inconstitucionalidade de qualquer tipo de prisão civil, exceto a do devedor de alimentos. Sendo assim, anote-se a ementa da referida decisão:

\begin{abstract}
PRISÃO CIVIL. Depósito. Depositário infiel. Alienação fiduciária. Decretação da medida coercitiva. Inadmissibilidade absoluta. Insubsistência da previsão constitucional e das normas subalternas. Interpretação do art. 5으, inc. LXVII e $\S \S 1^{\circ}, 2^{\circ}$ e $3^{\circ}$, da CF, à luz do art. $7^{\circ}$, § 7, da Convenção Americana de Direitos Humanos (Pacto de San José da Costa Rica). Recurso improvido. Julgamento conjunto do RE no 349.703 e dos HCs no 87.585 e no 92.566. É ilícita a prisão civil de depositário infiel, qualquer que seja a modalidade do depósito ${ }^{1}$.
\end{abstract}

Através do preâmbulo da Convenção Americana dos Direitos Humanos (CADH) infere-se: "de acordo com a Declaração Universal dos Direitos do Homem, só pode ser realizado o ideal do ser humano livre, isento do temor e da miséria, se forem criadas condições que permitam a cada pessoa gozar dos seus direitos econômicos, sociais e culturais, bem como dos seus direitos civis e políticos". ${ }^{2}$

Logo, a CADH, através de seus 81 artigos, buscou consolidar entre os países americanos, um estado com regime de justiça social e liberdade pessoal,

\footnotetext{
${ }^{1}$ BRASIL, STF - RE: 466343 SP, Relator: Min. CEZAR PELUSO, Data de Julgamento: 03/12/2008, Tribunal Pleno, Data de Publicação: DJe-104 DIVULG 04-06-2009 PUBLIC 05-06-2009 EMENT VOL-02363-06 PP-01106 RDECTRAB v. 17, n. 186, 2010, p. 29-165.

2 PORTAL BRASIL. Declaração Universal dos Direitos Humanos, op. cit.
} 
com o fito de que haja o cumprimento dos direitos humanos essenciais, como a garantia do direito à vida, à liberdade, à dignidade, à integridade pessoal e moral, à educação, bem como o direito à liberdade pessoal, dentre outros.

Deste modo, diante das disposições do supracitado tratado internacional, destacamos a previsão do direito à liberdade pessoal, tema abordado no artigo $7^{\circ}$, o qual instituiu e legalizou a Audiência de Custódia no Brasil, bem como em outros Estados-Membros.

Sendo assim, passa-se a expor:

ARTIGO $7^{0}$ - Direito à Liberdade Pessoal

1. Toda pessoa tem direito à liberdade e á segurança pessoais.

2. Ninguém pode ser privado de sua liberdade física, salvo pelas causas e nas condições previamente fixadas pelas constituições políticas dos Estados-Partes ou pelas leis de acordo com elas promulgadas.

3. Ninguém pode ser submetido a detenção ou encarceramento arbitrários.

4. Toda pessoa detida ou retida deve ser informada das razões da sua detenção e notificada, sem demora, da acusação ou acusações formuladas contra ela.

5. Toda pessoa detida ou retida deve ser conduzida, sem demora, á presenca de um juiz ou outra autoridade autorizada pela lei a exercer funcões judiciais e tem direito a ser julgada dentro de um prazo razoável ou a ser posta em liberdade, sem prejuízo de que prossiga o processo. Sua liberdade pode ser condiciona a garantias que assegurem o seu comparecimento em juízo.

6. Toda pessoa privada da liberdade tem direito a recorrer a um juiz ou tribunal competente, a fim de que este decida, sem demora, sobre a legalidade de sua prisão ou detenção e ordene sua soltura se a prisão ou a detenção forem ilegais. Nos Estados-Partes cujas leis prevêem que toda pessoa que se vir ameaçada de ser privada de sua liberdade tem direito a recorrer a um juiz ou tribunal competente a fim de que este decida sobre a legalidade de tal ameaça, tal recurso não pode ser restringido nem abolido. O recurso pode ser interposto pela própria pessoa ou por outra pessoa.

7. Ninguém deve ser detido por dívida. Este princípio não limita os mandados de autoridade judiciária competente, expedidos em virtude de inadimplemento de obrigação alimentar ${ }^{3}$.

Por conseguinte, nota-se que através da Convenção Americana dos Direitos Humanos tornou-se possível a implementação do instituto jurídico conhecido como Audiência de Custódia no Brasil. Este instituto, também conhecido como "Audiência de Garantia" prevê o direito da apresentação física do conduzido à autoridade judiciária para fins de apuração da legalidade da prisão, verificando-se ainda, a ocorrência de abusos pela autoridade policial, bem como 
a análise da necessidade da manutenção da custódia cautelar e/ou aplicação das medidas cautelares.

Por fim, vale dizer que o Instituto da Audiência de Custódia tem previsão normativa em vários Tratados Internacionais de Direitos Humanos, como por exemplo, o Pacto Internacional de Direitos Civis e Políticos (PIDCP), ao estabelecer em seu artigo 9.3 que "Qualquer pessoa presa ou encarcerada em virtude de infração penal deverá ser conduzida, sem demora, à presença do juiz ou de outra autoridade habilitada por lei a exercer funções judiciais (...)". A Convenção Europeia de Direitos Humanos, em seu artigo 5.3, no que lhe diz respeito, garante que "Qualquer pessoa presa ou detida nas condições do parágrafo 1, alínea "c", do presente artigo deve ser apresentada imediatamente a um juiz ou outro magistrado habilitado pela lei para exercer funções judiciais ${ }^{4}(\ldots)$ ". Note-se, finalmente que, apesar de variadas disposições sobre este assunto, o principal instrumento normativo ora utilizado será o Pacto de São José da Costa Rica, uma vez que se trata de Tratado Internacional que mais de perto vincula 0 Brasil. ${ }^{5}$

\subsection{O NEOCONSTITUCIONALISMO E OS PRINCÍPIOS PÁTRIOS APLICÁVEIS}

\section{AO DIREITO PROCESSUAL PENAL}

Foi através do Estado Constitucional de Direito que 0 Neoconstitucionalismo surgiu, propondo que a validação de uma norma não deve ser pautada unicamente no critério da competência normativa de quem a elaborou ou na análise da legalidade procedimental exigida para a elaboração de leis, mas sim que leis válidas são aquelas que submetem "a própria legalidade à Constituição, de modo que as condições de validade das leis e demais normas jurídicas dependem não só da forma de sua produção, como também da compatibilidade de seus conteúdos com os princípios e regras constitucionais". 6

Deste modo, emergiu um processo profundo de constitucionalização do Direito, ao ponto de que as regras constitucionais, o conteúdo inserido nas

4 Tribunal Europeu dos Direitos do Homem- Council of Europe. Convenção Européia dos Direitos do Homem. Disponível em: < http://www.echr.coe.int/Documents/Convention_POR.pdf>. Acesso em: 15/07/2017.

5 PAIVA, Caio. Audiência de Custódia e o Processo Penal Brasileiro. $1^{\underline{a}}$ ed. Florianópolis: Empório do Direto. 2015. p. 32

${ }^{6}$ Ibidem, p. 39. 
normas, bem como os princípios constitucionais são postos em destaque ao se analisar a validade de uma norma e que, neste compasso, o princípio da legalidade bem como o procedimento formal de elaboração de normas é direcionado à periferia.

Levando-se em conta as características deste constitucionalismo pósmoderno, bem como que nossa Carta Magna fora elaborada sob a influência de seus valores, é de suma importância a análise dos princípios constitucionais que fundamentam a aplicação da Audiência de Custódia.

Neste sentido, é indubitável que o instituto da audiência de custódia esteja enraizado aos preceitos dos princípios constitucionais, penais e processuais penais, de modo que estes servem veementemente para a devida aplicação deste novo instituto vigente no Brasil.

O Princípio da Presunção de Inocência, por exemplo, está, sem margem à dúvida, intrinsecamente interligado ao instituto jurídico da Audiência de Custódia, tendo em vista que, conforme o artigo $5^{\circ}$, inciso LVII, da Constituição Federal, antes de qualquer édito condenatório definitivo, ninguém poderá ser considerado culpado, tão pouco ter sua liberdade restringida sem justo motivo.

Logo, este princípio está inserido no Estado Democrático de Direito, assegurando a pessoa humana o direito de responder ao processo, em regra, em liberdade. Esta característica torna-se bastante eficaz, útil e necessária nas Audiências de Custódias, uma vez que mediante contato pessoal com a pessoa detida, o Juízo competente poderá decidir com mais segurança, a real necessidade processual de se restringir a liberdade de alguém.

Neste diapasão, Aury Lopes Júnior sabiamente concluiu que:

A partir da análise constitucional e também do artigo 9 da Declaração dos Direitos do Homem e do Cidadão, de 1789, VEGAS TORRES aponta para as três principais manifestações (não excludentes, mas sim integradoras) da presunção de inocência:

a) É um princípio fundante, em torno do qual é construído todo o processo penal liberal, estabelecendo essencialmente garantias para o imputado frente à atuação punitiva estatal;

b) É um postulado que está diretamente relacionado ao tratamento do imputado durante o processo penal, segundo o qual haveria de partir-se da ideia de que ele é inocente e, portanto, deve reduzir-se ao máximo as medidas que restrinjam seus direitos durante 0 processo (incluindo-se, é claro, a fase pré-processual); [....$^{7}$

${ }^{7}$ LOPES JÚNOR, Aury. Direito Processual Penal. 12ª ed. São Paulo: Saraiva. 2015. p. 93. 
Em síntese, a presunção de inocência exige que toda a privação de liberdade, antes do trânsito em julgado, deva conter natureza cautelar, através da imposição de ordem judicial devidamente motivada.

Ademais, não menos importante encontra-se o Princípio da Verdade Real, que busca fomentar a análise de caso de modo concreto pelo juízo, evitando-se que a autoridade competente analise de forma abstrata e fria o caso sob seu julgamento.

Através do princípio da verdade real, muito se contribui para 0 conhecimento dos fatos pelo juiz, uma vez que o contato pessoal com o preso garante maior elucidação dos fatos do que somente a análise dos autos (conjunto de documentos). Procedendo desta forma, promove-se o exercício da autodefesa e evita-se que haja arbitrariedades consubstanciadas em prisões ilegais e/ou desnecessárias.

Por fim, consigne-se também que a Audiência de Custódia emerge do exercício do Princípio da Ampla Defesa, isto porque, este princípio, encontrado no artigo $5^{\circ}, \mathrm{LV}$, de nossa Carta Magna, "confere à defesa a prerrogativa de produzir todas as provas necessárias ao exercício de seu direito. Inclusive, a ampla defesa se relaciona com o princípio da verdade real, uma vez que se assegura ao preso o direito de esclarecer o que realmente ocorreu, ou seja, a verdade dos fatos de modo a beneficiar a defesa". ${ }^{8}$

Sobre a importância do Princípio do Contraditório e da Ampla Defesa, Aury Lopes Junior argumentou que "o contraditório pode ser inicialmente tratado como um método de confrontação da prova e comprovação da verdade, fundando-se não mais sobe um juízo potestativo, mas sobre o conflito, disciplinado e ritualizado, entre partes contrapostas (...)".9

A garantia de participação das partes em todo o processo, consubstanciada na formação de provas para contribuir com a formação do convencimento do juiz nada mais é que o exercício do Contraditório e da Ampla Defesa. Este é inclusive o posicionamento da Escola Superior do Ministério Público, na obra "Audiência de Custódia. Da boa intenção à boa técnica”, cujos organizadores foram Mauro

\footnotetext{
${ }^{8}$ ARAÚJO, Davi. Audiência de custódia: lições preliminares. Disponível em: $<$ https://araujodavi.jusbrasil.com.br/artigos/190252425/audiencia-de-custodia > Acessado em: 16 de jun. de 2017.

${ }^{9}$ LOPES JÚNOR, Aury., op. cit., p. 94.
} 
Fonseca Andrade e Pablo Rodrigo Alflen, ao afirmarem que:

\begin{abstract}
O princípio do contraditório consiste na garantia de participação no processo como meio de permitir a contribuição das partes para a formação do convencimento do juiz e, assim, para o provimento final desejado. É preciso salientar que o contraditório é, sobretudo por ocasião das abordagens relativas às provas, um dos princípios mais caros ao processo penal, constituindo verdadeiro requisito de validade do processo, na medida em que a sua não observância é passível até de nulidade absoluta, quando em prejuízo do acusado. ${ }^{10}$
\end{abstract}

Logo, ao analisar os princípios do processo penal sob o viés do neoconstitucionalismo, denota-se que a Audiência de Custódia está totalmente encampada e prevista na norma mandamental. Ainda que ausente sua previsão expressa constitucional, referido instituto possui subsistência e fundamentação constitucional que justifique sua efetiva implementação, conforme explanado.

Não há possibilidade de se interpretar o sistema penal afastando um tipo de expediente como a Audiência de Custódia. O sistema processual penal constitucional se torna elevado diante de situações como a Audiência de Custódia, enquanto garantia do réu, possibilitando que este seja levado brevemente à presença de um juiz, de modo a sanar e até mesmo evitar vícios processuais; identificar e retirar a possibilidade de um estado de exceção, evitando-se ou diagnosticando e combatendo casos de tortura.

Por todo o exposto, denota-se que a influência do neoconstitucionalismo em nossa vigente Carta Magna elevou e norteou a possibilidade do legislador infraconstitucional e até mesmo os componentes do Poder Judiciário de fomentar e institucionalizar o instituto jurídico da Audiência de Custódia.

\title{
3 DEFINIÇÃO E ESPEQUE LEGAL DA AUDIÊNCIA DE CUSTÓDIA ENQUANTO CRIVO DA PRISÃO CAUTELAR
}

\subsection{ESTADO DE COISAS INCONSTITUCIONAL E A ADPF 347.}

Adiante se fará a definição da audiência de custódia, bem como se apresentará a resolução que regulamenta o instituto no país. Todavia, primordialmente se faz necessário relatar o contexto social brasileiro no tocante à prisão cautelar e o vergonhoso sistema de encarceiramento brasileiro como

10 ESCOLA Superior do Ministério Público. Audiência de Custódia. Da boa intenção à boa técnica. Porto Alegre. Ano: 2016. p. 18. 
grandes responsáveis de um "Estado de Coisas Inconstitucional".

O termo Estado de Coisas Inconstitucional (ECI) surgiu primeiramente na Colômbia, apesar de já terem outras cortes se posicionado dentro de seus preceitos anteriormente.

Nessa toada, o que esta técnica propõe, segundo os ensinamentos de Carlos Alexandre de Azevedo Campos, é identificar a existência de um quadro de violação generalizada e sistêmica de direitos fundamentais, causado pela inércia ou incapacidade reiterada e persistente das autoridades públicas em modificar tal conjuntura, de modo que apenas transformações estruturais da atuação do Poder Público e de uma pluralidade de autoridades podem modificar a situação constitucional11.

Logo, trata-se o sistema prisional brasileiro, diante de sua falha estrutural, de um verdadeiro Estado de Coisas Inconstitucional. Sobre a estrutura carcerária brasileira, Carlos Alexandre de Azevedo Campos assim teceu:

\begin{abstract}
À semelhança do caso colombiano, problemas de superlotação carcerária, instalações prisionais insalubres, tortura policial, falta de segurança interna, inexistência de medidas de divisão de presos, ausência de oferta de direitos básicos como saúde, alimentação minimamente saudável, educação e trabalho, número excessivo de prisões provisórias, assistência judiciária precária, entre outros, implicam tratamento desumano e condições indignas de sobrevivência dos presos $^{12}$.
\end{abstract}

Outrossim, a Clínica de Direitos Fundamentais da Faculdade de Direito da Universidade do Estado do Rio de Janeiro - Clínica UERJ Direitos apresentou, em estudo sobre o tema, os múltiplos modos de ofensa de diversos direitos fundamentais dos encarcerados, consubstanciados, dentre outros na:

\begin{abstract}
Superlotação, tortura, homicídios, violência sexual, celas imundas e insalubres, proliferação de doenças infectocontagiosas, comida intragável, falta de água potável e de produtos higiênicos básicos, corrupção, deficiência no acesso à assistência judiciária, à educação, à saúde e ao trabalho, domínio dos cárceres por organizações criminosas, insuficiência do controle estatal sobre o cumprimento das penas, discriminação social, racial, de gênero e de orientação sexual ${ }^{13}$.
\end{abstract}

${ }^{11}$ CAMPOS, Carlos Alexandre de Azevedo. O Estado de Coisas Inconstitucional e o litígio estrutural. Disponível em: < http://www.conjur.com.br/2015-set-01/carlos-campos-estado-coisasinconstitucional-litigio-estrutural >. Acesso em: 15/07/2017.

12 CAMPOS, Carlos Alexandre de Azevedo. Estado de Coisas Inconstitucional. Salvador: Editora JusPodivm. 2016, p. 265.

${ }^{13}$ CAMPOS, Carlos Alexandre de Azevedo, op. cit., p. 265. 
Por conseguinte, mais lamentável é expor que 34\% dos encarcerados no Brasil possuem sua liberdade cerceada de modo provisório ${ }^{14}$ isto é, são desprovidos de liberdade de locomoção enquanto ainda estão (ou deveriam estar) protegidos pelo princípio constitucional da Presunção de Inocência.

Ainda, Carlos Alexandra de Azevedo Campos continua expondo a usurpação dos direitos fundamentais ocasionada pelo sistema penitenciário brasileiro, ao relatar que:

[...] não contam com profissionais de saúde ou com medicamentos. Não possuem acesso ao trabalho, educação ou qualquer outra forma de ocupação do tempo. Além do ócio, convivem com as barbáries promovidas entre si. São constantes os massacres, homicídios, estupros, decapitação, estripamento e esquartejamento. A tortura policial também se faz muito presente, com espancamentos, estrangulamentos, choques elétricos, tiros com bala de borracha. A situação é ainda mais grave contra vulneráveis, como idosos, mulheres, deficientes físicos e homossexuais. Há casos publicamente conhecidos de mulheres dividindo celas com homens, sofrendo abusos sexuais, e de travestis sendo forçados à prostituição ${ }^{15}$.

Tudo isso revela o quadro de falência em que se encontra o sistema penitenciário brasileiro, de modo que não produz nada, senão mais violência. Assim concluiu Ana Paula de Barcellos, ao relatar que "o tratamento desumano conferido aos presos não é um problema apenas dos presos: a sociedade livre recebe os reflexos dessa política sob a forma de mais violência". ${ }^{16}$

Por todo o contexto fático e social acima descrito, não há dúvidas na afirmação de que o sistema carcerário brasileiro é um $\mathrm{ECl}$, tendo em vista que: a) os presídios por todo o Brasil violam de forma generalizada e sistêmica direitos fundamentais; b) a violação de garantias fundamentais é causada pela inércia ou incapacidade reiterada das autoridades pública de reverter essa situação; e, por fim c) a solução para esta problemática inconstitucional somente poderá ser amenizada diante de transformações estruturais da atuação do Poder Público, bem como de uma pluralidade de autoridades.

Foi neste sentido que a problemática inconstitucional ora discutida tornou-

14 Conselho Nacional de Justiça. Reunião Especial de Jurisdição. Disponível em: <http://www.cnj.jus.br/files/conteudo/arquivo/2017/02/b5718a7e7d6f2edee274f93861747304.pdf> . Acesso em: 28/07/2017.

${ }^{15}$ CAMPOS, Carlos Alexandre de Azevedo, op. cit., p. 267.

${ }^{16}$ BARCELLOS, Ana Paula de. Violência urbana, condições das prisões e dignidade humana.

Revista de Direito Administrativo № 254, 2010. 
se objeto da ADPF № 347/DF, da relatoria do ministro Marco Aurélio, cuja ação fora proposta pelo Partido Socialismo de Liberdade - PSOL que pediu, dentre outros, o reconhecimento expresso do $\mathrm{ECl}$ relativo ao sistema penitenciário brasileiro e a adoção de providências estruturais em face de lesões a preceitos fundamentais dos detentos.

A Arguição de Descumprimento de Preceito Fundamental de n. 334 ainda não fora definitivamente julgada, entretanto a liminar da ação já fora apreciada e, dentre os seus pedidos, apenas o "b" (relativo à implementação da audiência de custódia) e "h" (liberação das verbas do FUNPEN) foram atendidos em caráter inicial.

Assim, no momento de apreciação da medida cautelar, o Supremo Tribunal Federal, por maioria de votos, deferiu-a parcialmente, para determinar aos juízes e tribunais que, observados os artigos 9.3 do Pacto de Direitos Civil e Políticos e 7.5 do Pacto de São José da Costa Rica, realizem, em até 90 dias, a Audiência de Custódia, oportunizando o comparecimento do detido ou retido perante uma autoridade judiciária no prazo máximo de 24 horas, contados do momento do recolhimento, e à União que libere o saldo acumulado do Fundo Penitenciário Nacional para a finalidade para a qual foi criado, devendo abster-se de realizar novos contingenciamentos.

A ementa do acórdão ficou assim redigida:

CUSTODIADO - INTEGRIDADE FÍSICA E MORAL - SISTEMA PENITENCIÁRIO - ARGUIÇÃO DE DESCUMPRIMENTO DE PRECEITO FUNDAMENTAL - ADEQUAÇÃO. Cabível é a arguição de descumprimento de preceito fundamental considerada a situação degradante das penitenciárias no Brasil.

SISTEMA PENITENCIÁRIO NACIONAL - SUPERLOTACÃO CARCERÁRIA - CONDIÇÕES DESUMANAS DE CUSTÓDIA VIOLAÇÃO MASSIVA DE DIREITOS FUNDAMENTAIS - FALHAS ESTRUTURAIS - ESTADO DE COISAS INCONSTITUCIONAL CONFIGURAÇÃO. Presente quadro de violação massiva e persistente de direitos fundamentais, decorrente de falhas estruturais e falência de políticas públicas e cuja modificação depende de medidas abrangentes de natureza normativa, administrativa e orçamentária, deve o sistema penitenciário nacional ser caracterizado como "estado de coisas inconstitucional".

FUNDO PENITENCIÁRIO NACIONAL - VERBAS CONTINGENCIAMENTO. Ante a situação precária das penitenciárias, o interesse público direciona à liberação das verbas do Fundo Penitenciário Nacional.

AUDIÊNCIA DE CUSTÓDIA - OBSERVÂNCIA OBRIGATÓRIA. Estão obrigados juízes e tribunais, observados os artigos 9.3 do Pacto dos Direitos Civis e Políticos e 7.5 da Convenção Interamericana de Direitos Humanos, a realizarem, em até noventa dias, audiências de custódia, 
viabilizando o comparecimento do preso perante a autoridade judiciária no prazo máximo de 24 horas, contado do momento da prisão ${ }^{17}$.

Por fim, sobre o referido acórdão, Carlos Alexandre de Azevedo Campos afirmou que "a maioria dos ministros reconheceu, expressamente, estar presente um ECl. O relator apontou a violação sistemática de diversos direitos fundamentais do preso, o quadro de falhas estruturais e de falência de políticas públicas $^{18 " .}$.

Enfim, claramente possível dizer que não há porque temer a Audiência de Custódia; ela vem para humanizar o processo penal e representa uma importantíssima evolução, além de ser uma imposição da Convenção Americana de Direitos Humanos que ao Brasil não é dado o poder de desprezar.

\title{
3.2 DEFINIÇÃO E NECESSIDADE DO INSTITUTO ENQUANTO CRIVO DA PRISÃO CAUTELAR
}

Cumpre transcrever o que Caio Paiva cabalmente conceituou sobre o referido instituto, também conhecido como "Audiência de Garantia":

\begin{abstract}
A audiência de custódia consiste, portanto, na condução do preso, sem demora, à presença de uma autoridade judicial que deverá, a partir do prévio contraditório estabelecido entre o Ministério Público e a Defesa, exercer um controle imediato da legalidade e da necessidade da prisão, assim como apreciar questões relativas à pessoa 5 do cidadão conduzido, notadamente a presença de maus tratos ou tortura. Assim, a audiência de custódia pode ser considerada como uma relevantíssima hipótese de acesso jurisdição penal, tratando-se de uma das garantias da liberdade pessoal que se traduz em obrigações positivas a cargo do Estado. ${ }^{19}$
\end{abstract}

Logo, infere-se que o seu propósito então é o de garantir ao flagrado o direito de comparecimento, sem demora (prazo de 24 horas), perante um magistrado para uma entrevista pessoal que será acompanhada pelo Ministério Público e pelo Defensor (seja público ou privado). Em acontecimento desta audiência, discutir-se-ão se existem os critérios procedimentais estabelecidos no Código de Processo Penal (artigos 312e 313), para que só então, em caso

17 BRASIL. Supremo Tribunal Federal. Medida Cautelar na Arguição de Descumprimento de Preceito Fundamental 347. Relator: Min. Marco Aurélio. Brasília, 09 de setembro de 2015. Disponível em: < http://redir.stf.jus.br/paginadorpub/paginador.jsp?docTP=TP\&doclD=10300665 > . Acesso em 15/07/2017.

${ }^{18}$ CAMPOS, Carlos Alexandre de Azevedo, op. cit., p. 290.

19 PAIVA, Caio., op. cit., p. 31 
positivo, seja mantida a custódia cautelar do preso.

A existência, bem como a efetiva aplicabilidade do instituto da Audiência de Custódia, promoverá a identificação e o controle de prisões ilegais, desnecessárias ou até mesmo arbitrárias. É neste sentido que o magistrado será, de acordo com Badaró, um juízo "complexo ou bifronte", uma vez que:

\begin{abstract}
Não se destina apenas a controlar a legalidade do ato já realizado, mas também a valorar a necessidade e adequação da prisão cautelar, para o futuro. Há uma atividade retrospectiva, voltada para o passado, com vista a analisar a legalidade da prisão em flagrante e outra, prospectiva, projetada para o futuro, com escopo de apreciar a necessidade e adequação da manutenção da prisão ou, até mesmo, a simples revogação sem imposição de medida cautelar. ${ }^{20}$
\end{abstract}

Não obstante à análise sob o viés da legalidade, necessidade e adequação da manutenção do cárcere ou de possível concessão de liberdade, com ou sem imposição de medidas cautelares, frise-se também o importante papel da Audiência de Custódia em detectar a ocorrência de maus tratos ou tortura ocasionada no decorrer da condução do flagrante, bem como demais irregularidades.

Nesta perspectiva, este instituto jurídico oportuniza ao flagrado seu contato inaugural com o Poder Judiciário e igualmente viabiliza o exercício real e efetivo do princípio do contraditório e da ampla defesa, na oportunidade em que for ouvido em audiência, uma vez que poderá, caso não tenha o interesse de gozar do seu direito constitucional de permanecer em silêncio, descrever os fatos conforme a sua versão. ${ }^{21}$

Através desta perspectiva, torna-se viável considerar que a apresentação da pessoa presa perante juízo togado permite que este realize uma análise mais humanitária, evitando-se que com a rotina do exercício de sua profissão, o julgamento do caso concreto seja contaminado pela frieza da apreciação de mais um calhamaço de documentos, que por não poucas vezes representam episódios totalmente diversos da realidade. ${ }^{22}$

\footnotetext{
${ }^{20}$ BADARÓ, Gustavo Henrique Righi Ivahy. Parecer: prisão em flagrante delito e direito à audiência de custódia. Disponível em: <http://www.academia.edu/9457415/Parecer__Pris\%C3\%A3o_em_flagrante_delito_e_direito_\%C3\%A0_audi\%C3\%AAncia_de_cust\%C3\%B3 dia> Acessado em: 28 jun. 2017.

${ }^{21}$ Escola Superior do Ministério Público. Audiência de Custódia: da boa intenção à boa técnica. Porto Alegre. 2016. p. 19.

22 Ibidem, p. 19.
} 
Ademais:

(...) estará à presença do juiz o acusado, um sujeito de carne e osso, com nome, sobrenome, idade e rosto. $\mathrm{O}$ impacto humano proporcionado pelo agente, em suas primeiras manifestações, poderá modificar a compreensão imaginária dos envolvidos naquela solenidade. Merece destaque ainda que as decisões poderão ser tomadas com maiores informações sobre o agente, conduta e motivação, dando maior solidez nas decisões tomadas pelo magistrado na audiência de custódia. ${ }^{23}$

Por fim, denota-se que a mais elementar das finalidades da Audiência de Custódia é implementar a regular eficácia dos Tratados Internacionais dentro do território nacional, de modo que, por um lado, simultaneamente estará efetivando os direitos e garantias fundamentais da pessoa humana, bem como estará reafirmando o caráter supra legal dos tratados e, por outro lado, estará se sobrepondo àqueles opositores que não concordam com suas finalidades. ${ }^{24}$

O artigo 306 do Código de Processo Penal25 dispõe que "a prisão de qualquer pessoa e o local onde se encontre serão comunicados imediatamente ao juiz competente, ao Ministério Público e à família do preso ou à pessoa por ele indicada". O parágrafo $1^{\circ}$, por seu turno, estabelece que "Em até 24 (vinte e quatro) horas após a realização da prisão, será encaminhado ao juiz competente o auto de prisão em flagrante e, caso o autuado não informe o nome de seu advogado, cópia integral para a Defensoria Pública”.

Nota-se que as disposições do Código de Processo Penal a cerca do procedimento de comunicação do juízo sobre a prisão de qualquer pessoa é extremamente burocrático. Caio Paiva, sobre o tema, sabiamente argumentou:

Conforme se nota facilmente, trata-se de um sistema puramente cartorial, em que o Poder Judiciário, de forma asséptica, decide a partir do papel, sem garantir ao preso o direito de - pessoalmente - se fazer ouvir, revelando um padrão comportamental judicial que, com o passar dos tempos, se tornou praticamente gerencial, uma atividade quase burocrática, em que predomina a conversão do flagrante em prisão preventiva com base em elementos excessivamente abstratos, fomentando uma atividade decisória "em série" e customizada²6.

${ }^{23}$ LOPES JUNIOR, Aury; MORAIS DA ROSA, Alexandre. Processo penal no limite.

Florianópolis: Empório do Direito. 2015. p. 17.

24 PAIVA, Caio., op. cit., p. 34.

${ }^{25}$ BRASIL, Código de Processo Penal. Decreto lei no 3.689, de 03 de outubro de 1941.

${ }^{26}$ PAIVA, Caio., op. cit., p. 56. 
A solução, para tanto, fora apresentada por Giacomolli, ao asseverar que:

\begin{abstract}
Urge o cumprimento do determinado no art. 7.5 da CADH (...). Tanto nas hipóteses de flagrante delito convertido em prisão preventiva, quanto na decretação de prisão preventiva autônoma, o preso não é ouvido e nem apresentado ao juiz. Isso não ocorre imediatamente e nem em um prazo razoável. Com isso se descumpre a CADH e a CF, com o silêncio de toda a estrutura jurídica, em todos os níveis decisionais, postulatórios e doutrinários. O preso somente será ouvido quando da instrução processual e, como regra, no final do procedimento, meses após sua prisão. Nas situações em flagrante, o que é apresentado imediatamente ao juiz é a documentação da prisão, mas não o detido. Com isso, se esboroa e fragiliza o contraditório. Também, deveria ser cumprido o disposto no art. 8.1 da CADH ("toda pessoa tem direito de ser ouvida, com as devidas garantias e dentro de um prazo razoável, por um juiz ou Tribunal"). O direito à audiência, de ser ouvido, é um desdobramento da ampla defesa (defesa pessoal) e do contraditório, na medida em que se daria ao sujeito a possibilidade de expor as suas razões defensivas, possibilitando a concessão da liberdade provisória ou a substituição da prisão pelas cautelares alternativas. Com a apresentação imediata do deito, o Juiz poderia avaliar melhor a necessidade da prisão e das demais medidas cautelares, cumprindo o determinado na CADH. ${ }^{27}$
\end{abstract}

Assim, diante das dificuldades do Código de Processo Penal em atender as disposições inseridas na $\mathrm{CADH}$, bem como em outros tratados internacionais que versem sobre o tema, o Conselho Nacional de Justiça teve a iniciativa de dispor sobre o tema, ao passo que posteriormente os Tribunais de Justiça também regulamentaram o tema.

Nessa toada, com o fito de adequar o ordenamento jurídico brasileiro às disposições do art. 9º, item 3, do Pacto Internacional de Direitos Civis e Políticos das Nações Unidas, bem como do artigo 7º, item 5, da Convenção Americana sobre Direitos Humanos, o Conselho Nacional de Justiça (CNJ) elaborou a Resolução $213^{28}$, de 15 de dezembro de 2015, vigente desde $1^{\circ}$ de fevereiro de 2016, que dispôs sobre a apresentação de toda a pessoa presa à autoridade judicial no prazo de 24 horas.

A referida resolução fora elaborada com amparo na "letra "a" do inciso I do art. 96 da Constituição Federal, que defere aos tribunais a possibilidade de tratarem da competência e do funcionamento dos seus serviços e órgãos jurisdicionais e administrativos", bem como na Ação Direta de

${ }_{27}$ GIACOMOLLI, Nereu José. $\mathbf{O}$ devido processo penal: abordagem conforme a constituição Federal e o Pacto de São José da Costa Rica. São Paulo: Atlas, 2014, p. 364.

28 CONSELHO NACIONAL DE JUSTIÇA. Resolução CNJ no 213 de 15 de dezembro de 2015. Dispõe sobre a apresentação de toda pessoa presa à autoridade judicial no prazo de 24 horas. Disponível em:< http://www.cnj.jus.br/busca-atos-adm?documento=3059>. Acesso em: 15/07/2017. 
Inconstitucionalidade 5240 do Supremo Tribunal Federal ${ }^{29}$ que declarou a "constitucionalidade da disciplina pelos Tribunais da apresentação da pessoa presa à autoridade judicial competente".

Neste sentido, a Resolução 213 previu a forma como a Audiência de Custódia deve ser realizada no Brasil, dentre outras orientações. Do meio de suas disposições, destaca-se que, segundo o artigo 1을

[...] toda pessoa presa em flagrante delito, independentemente da motivação ou natureza do ato, seja obrigatoriamente apresentada, em até 24 horas da comunicação do flagrante, à autoridade judicial competente, e ouvida sobre as circunstâncias em que se realizou sua prisão ou apreensão ${ }^{30}$.

O parágrafo $1^{\circ}$ do artigo acima referido ainda expressamente previu que a comunicação da prisão em flagrante à autoridade judicial não supre a apresentação pessoal determinada no caput.

Ademais, salienta-se a vedação da presença dos agentes policiais responsáveis pela prisão ou pela investigação durante a audiência de custódia (art. 4aㅗ , parágrafo único), que evitará a possibilidade de intimidação do conduzido, bem como viabilizará a identificação de maus tratos ou tortura.

Importar notabilizar que um dos efeitos da implementação da Audiência de Custódia é possibilitar, de modo mais cristalino e atual, o acompanhamento de seus dados, através do Sistema de Audiência de Custódia (SISTAC), cuja criação está prevista no artigo $7^{\circ}$ da Resolução 213. Vejamos:

\begin{abstract}
Art. $7^{\circ} \mathrm{A}$ apresentação da pessoa presa em flagrante delito à autoridade judicial competente será obrigatoriamente precedida de cadastro no Sistema de Audiência de Custódia (SISTAC).

§ 1으 O SISTAC, sistema eletrônico de amplitude nacional, disponibilizado pelo $\mathrm{CNJ}$, gratuitamente, para todas as unidades judiciais responsáveis pela realização da audiência de custódia, é destinado a facilitar a coleta dos dados produzidos na audiência e que decorram da apresentação de pessoa presa em flagrante delito a um juiz e tem por objetivos:

I - registrar formalmente o fluxo das audiências de custódia nos tribunais; II - sistematizar os dados coletados durante a audiência de custódia, de forma a viabilizar o controle das informações produzidas, relativas às prisões em flagrante, às decisões judiciais e ao ingresso no sistema prisional;
\end{abstract}

${ }^{29}$ BRASIL. Supremo Tribunal Federal. ADI n. 5.240 SP. Ação Direta de Inconstitucionalidade. Provimento Conjunto 03/2015 do Tribunal de Justiça de São Paulo. Audiência de Custódia. Relator: Min. Luiz Fux. Brasília, 20 de agosto de 2015. Disponível em: < http://redir.stf.jus.br/paginadorpub/paginador.jsp?docTP=TP\&docID=10167333 > . Acesso em 15/07/2017.

${ }^{30}$ CONSELHO NACIONAL DE JUSTIÇA. Resolução CNJ no 213 de 15 de dezembro de 2015, op. cit. 
III - produzir estatísticas sobre o número de pessoas presas em flagrante delito, de pessoas a quem foi concedida liberdade provisória, de medidas cautelares aplicadas com a indicação da respectiva modalidade, de denúncias relativas a tortura e maus tratos, entre outras;

IV - elaborar ata padronizada da audiência de custódia;

V - facilitar a consulta a assentamentos anteriores, com o objetivo de permitir a atualização do perfil das pessoas presas em flagrante delito a qualquer momento e a vinculação do cadastro de seus dados pessoais a novos atos processuais;

$\mathrm{VI}$ - permitir o registro de denúncias de torturas e maus tratos, para posterior encaminhamento para investigação;

VII - manter o registro dos encaminhamentos sociais, de caráter voluntário, recomendados pelo juiz ou indicados pela equipe técnica, bem como os de exame de corpo de delito, solicitados pelo juiz;

VIII - analisar os efeitos, impactos e resultados da implementação da audiência de custódia ${ }^{31}$.

De acordo com 0 artigo $8^{\circ}$ da resolução em análise, a autoridade judicial deverá entrevistar a pessoa presa em consonância com alguns pressupostos, tal como o dever de esclarecer do que se trata a audiência de custódia e quais serão as questões analisadas, bem como indagar sobre as circunstâncias de sua prisão ou apreensão e sobre o tratamento recebido em todos os locais por onde passou antes da apresentação à audiência, interpelando sobre a ocorrência de tortura e maus tratos. ${ }^{32}$

Nessa toada, destaca-se também que, de acordo com o artigo $8^{\circ}$, inciso VIII e parágrafos $1^{\circ}$ e $3^{\circ}$, está vedada a discussão de mérito da prisão do agente, cingindo-se tal audiência de apresentação apenas: a) a análise de ocasional prática de tortura e maus tratos no momento da prisão; b) a deliberação quanto à legalidade e manutenção da prisão; c) ao cabimento de liberdade provisória sem ou com imposição de medidas cautelares diversas da prisão. ${ }^{33}$

Por fim, ainda ressalta-se que as pessoas presas em decorrência de cumprimento de mandados de prisão cautelar ou definitivo também são beneficiárias da Audiência de Custódia, no que couber.

Em suma, destacamos que a Resolução 213 do CNJ contempla as necessidades normativas para a efetivação e regimento da Audiência de Custódia.

A necessidade aplicação da Audiência de Custódia também fora apresentada em números pelo Conselho Nacional de Justiça ao afirmar que, em

\footnotetext{
31 Idem.

32 Idem.

33 Idem.
} 
média, foram evitadas 15 mil prisões, em 2015 com a aplicação do referido instituto. Ainda, o "CNJ também calcula a economia de R $\$ 40$ milhões dos cofres públicos gerada com o menor número de prisões e presos. O cálculo toma como base o custo mensal de R $\$ 3$ mil por detento". Estes dados foram oportunamente divulgados pela revista eletrônica "Consultor Jurídico" em 06 de janeiro de 2016. ${ }^{34}$

Em dados mais recentes, oriundo de um levantamento inédito realizado pela conceituada revista eletrônica "Consultor Jurídico" divulgado no site da revista em 27 de fevereiro de 2017, fora levantado que "dos mais de 140 mil presos em flagrante que tiveram a oportunidade de serem ouvidos por um juiz no ano passado (2016), nas audiências de custódia, 65 mil (46\%) conseguiram responder ao processo em liberdade, com fiança, relaxamento ou alguma medida cautelar". 35

Diante deste contexto, a Audiência de Custódia é uma medida eficaz ao combate de prisões cautelares ilegais, desnecessárias ou arbitrárias.

Não obstante aos benefícios da Audiência de Custódia acima descritos, infere-se também que, consequentemente, ela restringirá a quantidade de decretações de prisões cautelares, ao passo que se possibilitará o aparecimento de vagas dentro dos presídios e cadeias pelo país aos infratores cuja prisão é definitiva e àqueles cuja a restrição cautelar seja imperativa, o que possibilitará combater a falta de vagas e a decorrente superlotação carcerária no Brasil.

\section{CONCLUSÃO}

No que tange o uso desmedido de prisões cautelares, apresenta-se uma solução imediata, alcançável e eficaz: a Audiência de Custódia enquanto crivo às violações da dignidade da pessoa humana e às ofensas as garantias fundamentais.

Desta forma, introduzir a apresentação do preso à autoridade judiciária competente no Brasil é mais do que simplesmente cumprir o disposto em tratados internacionais, mas sim busca coibir prisões oriundas de atos ilegais, tortura e

\footnotetext{
${ }^{34}$ Audiências de custódia evitaram 15 mil prisões em 2015, afirma CNJ. Disponível em: $<$ http://www.conjur.com.br/2016-jan-06/audiencias-custodia-evitaram-15-mil-prisoes-2015cnj> Acessado em: 28 jun. 2017

35 LUCHETE, Felipe. Audiências de custódia liberaram 65 mil presos em todo o país em 2016. 2017. Disponível em <http://www.conjur.com.br/2017-fev-24/audiencias-custodia-liberaram65-mil-presos-pais-2016> Acessado em: 28 jun. 2017.
} 
outras práticas atentatórias aos princípios constitucionais, tal como o princípio da dignidade da pessoa humana e o da presunção de inocência.

Nessa toada, através da explanação crítica do crescimento dos direitos humanos, emergiu a elaboração do Pacto de São José da Costa Rica e demais tratados internacionais sobre o tema, como forma mundial de conter as acentuadas ofensas à dignidade da pessoa humana. Ademais, é nesta linha fática que o Neoconstitucionalismo e o Estado Constitucional de Direito, àquele que concede um maior valor axiológico à norma, passou a ser fomentado, tendo sido, inclusive, abarcado por nossa vigente Constituição Federal.

O presente trabalho, sob o viés caótico em que se encontra o sistema penitenciário brasileiro, estudou a Audiência de Custódia como uma maneira de se evitar que mais pessoas sejam submetidas às condições degradantes da segregação cautelar, de modo a fomentar o exercício do caráter excepcional da prisão, preceito que por muitos aplicadores do direito fora esquecido.

Desta forma, através da análise de dados e números nacionais oficiais, constatou-se um estado de superlotação carcerária no Brasil que revela mais do que somente números em uma tabela, ou seja, revela a quantidade tangencial de pessoas submetidas, frise-se que em 34\% das vezes sem um trânsito em julgado, a condições degradantes, ofensivas, desmoralizantes, que em nada contribuem para a resocialização.

O presente estudo, revelou estar, o sistema penitenciário pátrio, submerso a um verdadeiro Estado de Coisas Inconstitucionais, tendo em vista a generalizada ofensa aos direitos e garantias fundamentais do homem, ocasionada pela inércia ou incapacidade reiterada das autoridades públicas, de modo que as transformações para este quadro somente se dará mediante atuação em conjunto de autoridades.

A configuração deste Estado de Coisas Inconstitucionais em que o sistema penitenciário brasileiro está inserido fora inclusive reconhecido em sede de liminar da Arguição de Descumprimento de Preceito Fundamental n. 347, cuja uma das soluções acatadas pelos ministros fora a implementação, dentro de 90 dias, da Audiência de Custódia no país.

Logo, através deste trabalho, visualizou-se que por todo este contexto fático e problemático em que o Brasil se insere, faz-se necessário que haja a plena 
efetivação da Audiência de Custódia no país, afim de que, ao romper a barreira entre o juiz e o preso, seja dado azo a uma atuação jurisdicional mais humanizada, pois permitirá ao magistrado analisar a realidade, para só então decidir, fundamentadamente, pela manutenção da segregação da liberdade ou optar por outra medida cautelar diversa da prisão de forma mais segura.

Frise-se que este instituto não possui o objetivo de antecipar a persecução penal, de modo que durante a sua realização, somente analisar-se-ão os requisitos previstos no Código de Processo Penal atinente aos preceitos justificadores da prisão cautelar, ficando vedada a análise do mérito que ensejou a prisão.

Por fim, através do ativismo protagonizado pelo CNJ na Resolução no 213 de 2015, o Brasil passou a regulamentar a Audiência de Custódia, e, apesar de pouco tempo desde a sua aplicação, já colhemos os frutos de sua benesse, o que fora apresentado neste estudo através de dados que informaram que entre as pessoas submetidas a esta audiência, 46\% puderam responder ao processo em liberdade ou foram submetidos a outras cautelares diversas da prisão.

Desta feita, apresentamos a Audiência de Custódia como uma simples medida, que apesar de não demandar grande deslocamento no Poder Judiciário, é capaz de criar uma mudança exponencial no sistema de prisões cautelares do Brasil, de modo a evitar a segregação desmedida e sem crivo. 


\section{REFERÊNCIAS}

ALEXY, Robert. Tradução: Virgílio Afonso da Silva. Teoria dos direitos fundamentais. São Paulo: Malheiros, 2008.

ARAÚJO, Davi. Audiência de custódia: lições preliminares. Disponível em: <https://araujodavi.jusbrasil.com.br/artigos/190252425/audiencia-de-custodia> Acesso em: 16/06/2018.

Audiências de custódia evitaram 15 mil prisões em 2015, afirma CNJ. Disponível em: <http://www.conjur.com.br/2016-jan-06/audiencias-custodiaevitaram-15-mil-prisoes-2015-cnj>. Acesso em: 28/06/2018.

BADARÓ, Gustavo Henrique Righi Ivahy. Parecer: prisão em flagrante delito e direito à audiência de custódia. Disponível em: <http://www.academia.edu/9457415/Parecer_Pris\%C3\%A3o_em_flagrante_deli to_e_direito_\%C3\%A0_audi\%C3\%AAncia_de_cust\%C3\%B3dia> Acesso em: $28 / 06 / 2018$.

BARCELLOS, Ana Paula de. Violência urbana, condições das prisões e dignidade humana. Revista de Direito Administrativo № 254, 2010.

BRASIL, Código de Processo Penal. Decreto lei no 3.689, de 03 de outubro de 1941.

Supremo Tribunal Federal. ADI n. 5.240 SP. Ação Direta de Inconstitucionalidade. Provimento Conjunto 03/2015 do Tribunal de Justiça de São Paulo. Audiência de Custódia. Relator: Min. Luiz Fux. Brasília, 20 de agosto de $2015.2 \quad$ Disponível em: < http://redir.stf.jus.br/paginadorpub/paginador.jsp?docTP=TP\&doclD=10167333 >. Acesso em 15/07/2017.

Supremo Tribunal Federal. Medida Cautelar na Arguição de Descumprimento de Preceito Fundamental 347. Relator: Min. Marco Aurélio. Brasília, 09 de setembro de 2015. Disponível em: < http://redir.stf.jus.br/paginadorpub/paginador.jsp?docTP=TP\&doclD=10300665 >. Acesso em 16/06/2018.

, Supremo Tribunal Federal - RE: 466343 SP. Relator: Min. Cezar Peluso, Data de Julgamento: 03/12/2008, Tribunal Pleno, Data de Publicação: DJe-104 DIVULG 04-06-2009 PUBLIC 05-06-2009 EMENT VOL-02363-06 PP-01106 RDECTRAB v. 17 , n. 186, 2010, p. 29-165.

CAMPOS, Carlos Alexandre de Azevedo. Estado de Coisas Inconstitucional. Salvador: Editora JusPodivm. 2016.

CAMPOS, Carlos Alexandre de Azevedo. O Estado de Coisas Inconstitucional e o litígio estrutural. Disponível em: < http://www.conjur.com.br/2015-set01/carlos-campos-estado-coisas-inconstitucional-litigio-estrutural >. Acesso em: 16/06/2018. 
Conselho Nacional de Justiça. Resolução CNJ no 213 de 15 de dezembro de 2015. Dispõe sobre a apresentação de toda pessoa presa à autoridade judicial no prazo de 24 horas. Disponível em:< http://www.cnj.jus.br/busca-atosadm?documento=3059>. Acesso em: 15/07/2017.

Conselho Nacional de Justiça. Reunião Especial de Jurisdição. Disponível em: <http://www.cnj.jus.br/files/conteudo/arquivo/2017/02/b5718a7e7d6f2edee274f93 861747304.pdf>. Acesso em: 28/06/2018.

ESCOLA Superior do Ministério Público. Audiência de Custódia. Da boa intenção à boa técnica. Porto Alegre. Ano: 2016.

GABRIELE, Ana Claudia. A influência do Pacto de San José da Costa Rica na Constituição Federal: Direitos humanos essenciais. Disponível em: $<$ https://acgabriele.jusbrasil.com.br/artigos/397438886/a-influencia-do-pacto-desan-jose-da-costa-rica-na-constituicao-federal>. Acessado em: 16/06/2018. GIACOMOLLI, Nereu José. O devido processo penal: abordagem conforme a constituição Federal e o Pacto de São José da Costa Rica. São Paulo: Atlas, 2014.

GIACOMOLLI, Nereu José. Prisão, liberdade e as cautelares alternativas ao cárcere. São Paulo: Marcial Pons, 2013.

Levantamento dos presos provisórios do país e plano de ação dos tribunais. 2017. Disponível em: <http://www.cnj.jus.br/noticias/cnj/84371-levantamento-dospresos-provisorios-do-pais-e-plano-de-acao-dos-tribunais>. Acesso em: 28/06/2018.

LOPES JÚNIOR, Aury. Direito Processual Penal. 11 ed. SP: Saraiva, 2014.

2015. , Aury. Direito Processual Penal. $12^{\mathrm{a}}$ ed. São Paulo: Saraiva, , Aury. Prisões cautelares. 5a . ed. São Paulo: Saraiva. 2017. Aury; MORAIS DA ROSA, Alexandre. Processo penal no limite. Florianópolis: Empório do Direito.

LUCHETE, Felipe. Audiências de custódia liberaram 65 mil presos em todo o país em 2016.

2017. Disponível em <http://www.conjur.com.br/2017-fev-24/audienciascustodia-liberaram-65-mil-presos-pais-2016> . Acesso em: 28 jun. 2018.

MESSA, Ana Flávia. Curso de direito processual penal. 2. ed. São Paulo: Saraiva, 2014.

MIRABETE, Júlio Fabbrini. Processo Penal. 11ª ed. São Paulo: Atlas. 2006. 
MOTTA, Artur Francisco Mori Rodriguês. A dignidade da pessoa humana. Disponível em: $<$ http://www.ambitojuridico.com.br/site/?n_link=revista_artigos_leitura\&artigo_id=14054>. Acesso em: 16/06/2018.

ONU. Declaração Universal dos Direitos Humanos. 2009. Disponível em $<$ http://www.brasil.gov.br/cidadania-e-justica/2009/11/declaracao-universal-dosdireitos-humanos-garante-igualdade-social>. Acesso em: 15/06/2017.

PAIVA, Caio. Audiência de Custódia e o Processo Penal Brasileiro. $1^{\text {a }}$ ed. Florianópolis: Empório do Direto, 2015.

RANGEL, Paulo. Direito Processual Penal. 23ª ed. São Paulo: Atlas. 2015. p. 770.

Tribunal Europeu dos Direitos do Homem - Council of Europe. Convenção Européia dos Direitos do Homem. Disponível em: < http://www.echr.coe.int/Documents/Convention_POR.pdf>. Acesso em: 15/07/2017.

WERMUTH, Maiquel Ângelo Dezordi. A Dimensão (Des)Humana do Processo de Expansão do Direito Penal: o papel do medo no e do Direito Punitivo brasileiro e o disciplinamento das classes populares. 2010. 149 p. Dissertação (Mestrado em Direito) - Faculdade de Ciências Jurídicas, Universidade do Vale do Rio dos Sinos, São Leopoldo, Rio Grande do Sul.

ZAFFARONI, Eugenio Raúl. Globalização, Sistema Penal e Ameaças ao Estado Democrático de Direito. In: KARAN, Maria Lúcia (org.). Globalização, Sistema Penal e Ameaças ao Estado Democrático de Direito. Rio de Janeiro: Lumen Juris, 2005, p. 17-38. 